\title{
3. Social dialogue at the dawn of the ILO's centenary: sorting out challenges, setting priorities for the future
}

\author{
Konstantinos Papadakis
}

\subsection{INTRODUCTION}

The rejuvenation of democratic institutions and effective public administration - including labour administration - is often associated with direct civil society involvement in public policy making. The underlying assumption is that when institutions allow all potentially affected groups (in addition to public actors) to be involved in policy making, shape its agenda and formulate solutions, the policymaking process contributes to "a richer texture of democracy" and more effective outcomes. ${ }^{1}$ In the area of labour administration, this logic has been reflected in the establishment, in many countries, of a variety of processes and "bodies ... for consultation with and participation by employers and workers and their organizations". ${ }^{2}$ Involving workers and employers (which the ILO refers to as the social partners) in policy making is crucial not only in order to ensure more informed design of labour policy, but also more effective services - social partners knowing better than anyone the workplace challenges and their impacts and being able to detect appropriate responses. Importantly, the participatory dimension of such processes improves consensus on their outcomes (labour policies, laws, dispute prevention and resolution), a condition sine qua non for successful implementation. The combined effect of informed policy design and better ownership leads to enhanced labour administration systems, the underlying objective of ILO Convention No. 150 on Labour Administration.

From an ILO perspective, such direct civil society involvement in public policy making is captured in the notion of "social dialogue" which describes the involvement of workers, employers and governments in decision-making on employment and workplace issues. Social dialogue includes all types of negotiation, consultation and exchange of information among representatives 
of these groups on common interests in economic, labour and social policy. It can be bipartite, between workers and employers, or tripartite, including government (ILO, 2013).

Achieving social justice through tripartite cooperation has been the overarching objective of the ILO since its creation, and indeed the added-value of the ILO within the United Nations (UN) system. ${ }^{3}$ As the organization celebrated its centenary in 2019, social dialogue and tripartism remained firmly at the centre of the ILO mandate, its structure, normative action and Decent Work Agenda. Social dialogue is the ILO's governance paradigm for addressing contemporary socio-economic challenges, achieving internationally set objectives such as the 2030 Agenda for Sustainable Development (2030 Agenda) and the Sustainable Development Goals (SDGs), and making a firm contribution to attaining social justice around the world.

Yet, in a rapidly changing international environment, shaped inter alia by new technologies, evolving business models and increasing environmental awareness, important challenges for the ILO and its constituents (governments, workers' and employers' organizations) persist or are emerging, which compel social dialogue actors and institutions to adjust their capacities and services. ${ }^{4}$ The COVID-19 pandemic, which has been unfolding its devastating socio-economic impacts, disrupting business and supply chains and impacting vulnerable workers on an unprecedented global scale, shows that these challenges are set to amplify (ILO, 2020a). ${ }^{5}$

The present chapter discusses a number of social dialogue-related challenges with which the ILO and its tripartite constituents are faced in their shared quest for economic and social progress. It draws on recent and ongoing research and ILO policy debates on the evolution of the practice of social dialogue within such changing environment. ${ }^{6}$ Section 3.1 introduces the context within which social dialogue evolves, and ensuing priorities for labour administrations and social partners. Section 3.2 recalls the importance of making social dialogue actors and institutions more inclusive. Section 3.3 discusses the crucial question of policy coherence, and the related debate on social dialogue and economic performance. Section 3.4 presents overall trends characterizing labour law reforms shaping social dialogue. Section 3.5 is concerned with the emerging layer of social dialogue beyond national borders - which is important for the sound governance of globalization. Section 3.6 discusses the role of civil society organizations, other than workers' and employers' organizations. We conclude with a discussion of the question of societal trust in institutions, a condition sine qua non, if social dialogue is to be used to its full potential. 


\subsection{THE CONTEXT OF SOCIAL DIALOGUE}

Social dialogue is inextricably bound up with the evolving global environment and the many opportunities and challenges that shape this environment. Widening income inequality, extensive informality, a declining wage share in many countries' GDP, eroding collective bargaining in some countries, regulatory rigidities that may hinder social dialogue, the changing nature of work and the employment relationship, the falling membership of some workers' and employers' organizations, and weakening labour market institutions are interrelated factors challenging social dialogue and its actors at all levels. ${ }^{7}$ In spite of the widespread existence of formal tripartite or bipartite procedures, ${ }^{8}$ there is a parallel decline in the use of forms of social dialogue that produce binding commitments, such as collective bargaining and processes that lead to the conclusion of social pacts (Baccaro and Galindo, 2018). These challenges create, inter alia, a fertile ground for reproaches of declining representative legitimacy of the partners to engage in social dialogue and concerns over the effectiveness of social dialogue in regulating the socio-economy.

Changes in technology, demography, climate change and environmental policies, and deepening globalization, which accelerate in pace and depth, further challenge social dialogue (ILO, 2019a). So far, their benefits have not been equitably shared, nor the burdens fairly distributed, and social dialogue finds difficulty in adjusting in spite of signs of institutional innovation (Hayter, 2015: 1-4).

First, current technological revolutions such as increasing automation and digitization, are having a profound and transformative impact on the world of work. On-demand or gig economy types of work, for instance, neither take the form of traditional dependent employment nor occur in typical workplaces. The emergence of these types of work creates jobs opportunities; yet such jobs or gigs have (further) blurred the contours of the employment relationship, on the basis of which the functions of labour administrations and labourmanagement cooperation have historically been built and operated. This raises fundamental questions as to how to ensure that social dialogue's actors and institutions remain relevant to, and representative of, their constituents. With traditional standard employment relationships eroding, no doubt alternative organizational forms, or existing ones, will need to meet the needs of those in the informal economy, the self-employed and gig workers, ensure the collective representativeness of workers, business units and employers affected by this trend, and protect their interests. Unionization, worker centres, cooperatives, freelancer associations, entrepreneurs and small business associations, and online forums represent a host of initiatives aimed at fostering collective 
action and increase representation opportunities for workers (Johnston and Land-Kazlauskas, 2018).

Second, demography-related challenges, migration movements and refugee crises due to wars, climate change, poverty and unemployment in sending countries constitute a burden on both the global North (which ages) and on the global South (which is staying young). In both cases, shifts in demography are set to further challenge labour market institutions in terms of retaining or absorbing workers. International economic migration policies have been developed through tripartite consultations in some countries. ${ }^{9}$ Yet, surveys of migration and mobility professionals across all regions and industries more often than not find that very few organizations are able to influence national migration policies (ILO, 2017a). The ILO's Committee of Experts on the Application of Conventions and Recommendations has noted that workers' and employers' organizations are barely or not at all consulted by governments on labour migration or are rarely part of national commissions dealing with it (ILO, 2016b). Such organizations are infrequently invited to negotiations on bilateral and multilateral agreements that touch upon labour migration.

Third, given climate change, moving towards a low-carbon future requires costs and benefits to be measured in terms of job destruction or creation and increased inequality, ${ }^{10}$ and to be managed carefully and in a participatory way and so fairly distributed - as spelled out in sustainable development discourses developed since the 1992 United Nations Conference on the Environment and Development, which have been getting more traction since the adoption of the Paris Agreement under the United Nations Framework Convention on Climate Change. ${ }^{11}$ In some countries, the social partners are engaged in project steering committees that define work programmes and guide and monitor green job projects. In several countries, green jobs assessments at the national and sectoral levels have reviewed the scope and investment needs for green sector development, potential for the creation and expansion of sustainable enterprises and value chains, and the skills needed for green jobs. ${ }^{12}$ Yet, the capacities of labour administrations and social partners in this respect may lag behind actual needs in most parts of the world, showing a still shaky political will to prioritize in policy making the transition to a low-carbon future-admittedly one of the world's greatest challenges in the 21 st century.

Last but not least, while globalization has contributed to eradicating poverty in many parts of the world, ${ }^{13}$ for some it has become the symbol of long-term economic stagnation, high unemployment, the primacy of financial targets over macroeconomic and employment targets, the falling shares of national incomes going to workers, and a shrinking welfare state. ${ }^{14}$ The disillusionment that this situation has created among populations across the globe threatens not only free-market concepts (the basis of globalization) but also some of the basic values of the democratic process. An unprecedented backlash against 
the - actual or perceived - failure of globalization to make a positive contribution to social justice has upset numerous political systems around the world, with the rise into power of anti-establishment and populist movements that could shake up political systems and the practice of democracy (Economist Intelligence Unit (EIU), 2018). In this context social dialogue is confronted with the broader challenge of declining trust in institutions. We return to this point in the conclusion.

The magnitude of the disruptive force of the COVID-19 pandemic is likely to lead to an acceleration of these trends. For instance, the pandemic and the lockdown paved the way to a widespread use of telework arrangements, accelerated the diffusion of new business models based on digitization of services and the use of online commerce and increased automation in industries. ${ }^{15}$ It has also boosted ecological awareness and debates on the need to design economies that mitigate the threats of climate change, biodiversity loss and pandemics. ${ }^{16}$ Importantly, the COVID-19 pandemic has also been posing obstacles to democracy, human rights and fundamental freedoms, with a noteworthy number of states, for instance, having (temporarily) derogated from their Constitutions and international human rights treaties, after having declared the state of emergency. ${ }^{17}$ During a discussion of social dialogue and tripartism that took place at the 2018 International Labour Conference (ILC), states and social partners acknowledged that in order to anticipate and manage the impacts of these changes, there is a need for continuous support on strengthening the main forms of social dialogue: peak level national and sectoral social dialogue, collective bargaining, workplace cooperation and social dialogue at the cross-border level. ${ }^{18}$ However, strengthening social dialogue machineries is not enough. Social partners and labour administrations require also stronger capacities in policy formulation shaping the contents and implementation of labour law and industrial relations. For instance, the digital (platform) economy and the transition to a green economy require capacitating labour administrations in order to anticipate and manage the impacts of such changes on their constituents, not least for preventing or managing conflicts generated by such changes. Such assistance needs to take into account not only ministries of labour - the traditional counterpart of the ILO - but all other relevant parts of government (dealing with development, finance, environmental protection and so on). Employers' organizations are called upon to strengthen their capacity to provide services to their members that take advantage of the new realities shaping labour-management relations and become attuned to changing production and work requirements. Finally, workers' organizations, are called upon to strengthen the collective voice of vulnerable workers, ${ }^{19}$ and workers engaging in diverse forms of employment and non-standard forms of employment who, more frequently than other workers, lack protection in law or in practice, let alone an institutional voice. 
In the context of the ILO's Future of Work Initiative, national tripartite dialogues in over 113 countries mapped constituents' proposals on action that could be undertaken by labour administrations and the social partners in order to adapt to new realities shaping the world of work (ILO, 2017b). These included: the use of tripartite social dialogue for facilitating transitions and ensuring equitable distribution of costs and benefits and social welfare support (Cameroon, Italy, the Netherlands and Rwanda); launching tripartite social dialogue on the evolution of the employer-employee relationship with a view to adopting new, yet flexible, rules for protecting workers (Senegal and Panama); using collective bargaining to address the challenges of technology, digitization and new forms of organizing work and preventing fundamental principles and rights of work from being undermined or circumvented (Belgium, Germany, Kenya, Spain and Switzerland); enhancing the representation by the social partners of actors in the social economy (cooperatives), small and medium enterprises (SMEs) and the informal economy (France); exploring new mechanisms (including the use of information technology and virtual communities) for organizing and representing the self-employed, independent contractors, and gig or platform economy workers by type of jobs or region (Japan). The new context created by the pandemic has further reinforced the relevance of these areas of action.

\subsection{PRECONDITIONS FOR SOCIAL DIALOGUE AND INCLUSION IN SOCIAL DIALOGUE}

Social dialogue still fails to reach billions of workers. Today, despite economic progress more than 61 per cent of the world's working population aged 15 and over are in informal employment. ${ }^{20}$ Frequently, informal and rural workers but also workers in non-standard employment, new and emerging types of jobs or gigs, and vulnerable groups fall outside the protection of labour law and the scope of social dialogue. This challenge is hardest in countries lacking an enabling environment for credible social dialogue - a key precondition being the existence of freedom of association, and strong, democratic, independent and representative organizations interacting in conditions of mutual trust and respect. ${ }^{21}$ Social dialogue during the initial phase of the pandemic in early 2020 further illustrated this trend: rare have been those instances of bipartite and tripartite social dialogue focusing on groups highly exposed to the impacts of the pandemic, such as self-employed, migrant workers and workers and business units of the informal economy (ILO, 2020c). In this context, the quest for inclusiveness remains critical.

The ILO's response in favour of inclusiveness has taken the form of both policy and normative action. On the policy side, it has prioritized the strengthening of its promotional activities on policy advice, targeted capacity 
building and evidence-based policy advice and advocacy. It has encouraged governments to dedicate more financial resources to labour administrations and to make better use of information technology so as to increase efficiency and close gaps in governance and coverage gaps for groups still largely outside their scope. It has also encouraged social partners to pursue their efforts in organizing and representing hard-to-organize workers and businesses.

The ILO has also adjusted its normative agenda towards the coverage of the "voiceless" including through the adoption of standards attributing a key role for labour administrations and the social partners in tackling informality. ${ }^{22}$ The 2015 Recommendation No. 204 concerning the Transition from the Informal to the Formal Economy explains in the most explicit terms the role of labour administrations, the social partners and social dialogue:

When formulating and implementing an integrated policy framework, Members should ensure coordination across different levels of government and cooperation between the relevant bodies and authorities, such as tax authorities, social security institutions, labour inspectorates, customs authorities, migration bodies and employment services, among others, depending on national circumstances ... Members should create an enabling environment for employers and workers to exercise their right to organize and to bargain collectively and to participate in social dialogue in the transition to the formal economy ... Employers' and workers' organizations should, where appropriate, extend membership and services to workers and economic units in the informal economy. (para 12, para 32, para 33)

Undoubtedly, in the post COVID-19 pandemic era, governments and social partners will come increasingly under pressure to speed up legal and policy changes and institutional innovations to facilitate transitions from informal to formal economy, fill the gaps in labour legislation, put in place enabling environment for sustainable enterprises, and make social dialogue more representative of voiceless or hard-to-organize groups. In case of inaction, or mild action in this area, the risk of declining credibility of social dialogue and effectiveness of labour laws is tangible.

\subsection{IMPROVING POLICY COHERENCE}

The question of policy coherence has been at the top of the agenda of many states and international organizations for many years now. ${ }^{23}$ The underlying assumption is that due to the complexity and interconnectedness of contemporary socio-economic issues and the multiplicity of actors operating at various levels (with not necessarily the same mandates), there is all too often a lack of basic common views both in terms of goals and means of action. Without coordination across policy areas aiming at the same general socio-economic 
goals within national, regional or local governments, and without international collaboration, social progress can be achieved only partially, if at all.

In the last decade there have been three major developments which, more or less directly, are expected to reinstate the value of social dialogue in socio-economic policy making, and pave the way towards more coherence between the objectives of economic growth and the generation of decent work for all, but also more coherent policy advice by international organizations as an essential element in developing effective strategies.

The first development has been the global consensus, reached in 2015, on the need for international cooperation as a follow-up to the Millennium Development Goals, as contained in the 2030 Agenda and the 17 SDGs. The need for "participatory governance" including social dialogue, as a major means for implementing the SDGs is now squarely on the political agenda. There are also indications that the SDGs can contribute to revitalizing social dialogue at the national level, given that social dialogue is an integral part of the 2030 Agenda - particularly Goal 8, which aims to promote sustained, inclusive and sustainable economic growth, full and productive employment and decent work for all, and Goal 16, on promoting peaceful and inclusive societies for sustainable development, providing access to justice for all and building effective, accountable and inclusive institutions at all levels (TUDCN and ILO, 2018). Yet, participatory governance does not necessarily come without challenges for social dialogue. We return to this point in Section 3.6.

The second development has been the increasing recognition, including by strong proponents of the free market (such as the international financial institutions - IFIs), that the rise of income inequality is a major issue to address. The UN, World Bank, the International Monetary Fund (IMF), Organisation for Economic Co-operation and Development (OECD) and G20 seem to share a broad consensus on the need to tackle poverty and inequality, going beyond the social angle to comprehend the benefits of removing these scourges from an economic perspective. ${ }^{24}$ This emerging consensus generates rays of hope on the need for more social dialogue and social concertation to share the benefits of growth beyond the top of the income scale.

A third development has been the extensive use of social dialogue across the globe during the initial phase of the COVID-19 pandemic, alongside a massive fiscal response to mitigate the socio-economic impacts of the pandemic. ${ }^{25} \mathrm{In}$ order to increase health capacity, replace lost household income and prevent large-scale bankruptcies, social partners engaged in bipartite and tripartite social dialogue at all levels - enterprise, sector, national, cross-border. They provided crucial information for the design and implementation of emergency policies and measures and reached multiple agreements to support business and workers, for instance on health and safety protocols preventing the propagation of the virus at workplaces, job retention, protecting wages and 
ensuring business continuity, but also on broader socio-economic national and cross-border responses (ILO, 2020b). Yet, social dialogue may not be immune to a risk of marginalization if governments shift policy priorities from economic stimulus (at the time of the writing of the present chapter) towards fiscal consolidation and debt reduction. While fiscal policy is not a purely labour issue, it has certainly many implications for labour markets, not least as it can affect wages and lead to public spending cuts. Mature social dialogue can play a key role in offsetting the most serious consequences of fiscal policy decisions on workers and businesses.

To capitalize on these positive developments, the ILO and its constituents are called upon to demonstrate the business case for social dialogue and tripartism. This is not an easy task due to diverging theoretical approaches underpinning the actions of different national administrations and international organizations, and which seem to persist.

\subsubsection{Social Dialogue and Economic Performance}

The neo-classical economics approach has often perceived trade unions and social dialogue - notably collective bargaining - as factors inducing a labour market distortion that constrains the free functioning of labour markets and results in suboptimal economic outcomes. ${ }^{26}$ Arguments from this standpoint generally stress the monopoly consequences of trade unionism and labour market segmentation as the principal distortions. It is claimed for instance that collective bargaining leads to above market-clearing wages outcomes, with either unemployment and/or the displacement of workers to the non-union sector and cluster of low-wage workers as a consequence. These "insider/ outsider" and "labour elite" theories often see in social dialogue the reason behind burgeoning informal economy and claim that economic actors can better adjust to market changes without social dialogue or labour laws that provide employment protection.

At the opposite pole are Keynesian and institutional economic theories. These theories see the role of civil society, notably workers' organizations and social dialogue as positive. They claim that trade union voice improves the quality of managerial decisions by making such decisions better informed and more likely to be implemented. Social dialogue can contribute to an increase in productivity through more stable labour relations, lower turnover and improvements in workplace practices. They see in collective bargaining a factor for wage increases beyond what the market might offer, thus reducing wage inequality, and for increased aggregate demand in economies, which is necessary for sustainable enterprises. They found no evidence that trade union density has an impact on overall economic performance measured by GDP, or that that social dialogue contributes to the expansion of the informal economy. 
On the contrary, ILO research has shown a clear inverse correlation between collective bargaining coverage and inequality (the higher the coverage, the lesser the inequality) (Hayter and Weinberg, 2011; ILO, 2015a). The 2018 ILO Global Wage Report emphasized the importance of collective bargaining in closing also gender pay gaps, when complemented by statutory minimum wage legislation (ILO, 2018a).

The neo-classical and Keynesian approaches to social dialogue and labour protection seemed to slowly converge since the 2008 crisis, raising hopes for much-needed policy coherence. For instance, in 2013, the ILO welcomed the publication of the World Bank's World Development Report entitled "Jobs" which updated the organization's policy prescriptions on employment and development. The Bank acknowledged, inter alia, that there is ample space for governments and societies to decide on the desired level of labour protection and regulations and recognized that social cohesion is an important objective of development. Similarly, the IMF's 2015 Guidance Note for Surveillance under Article IV Consultations invited its staff to "routinely request meetings with political leaders (e.g. parliamentarians), trade unions, business representatives and civil society organizations" with a view to helping to stimulate public policy debate (IMF, 2015).

However, the ensuing years showed that there is still a long way to go before achieving a common understanding on the role of workers and employers in policy making, to ensure fairness, inclusion, social cohesion and stability. On-the-ground interventions by international financial institutions (IFIs) in Europe on the occasion of structural adjustment programmes linked to the public debt crisis, notably in the European South and in Ireland, promoted changes to national systems of industrial relations and labour administrations that often led to less, not more, social dialogue and public deliberation (Papadakis and Ghellab, 2014: 1-4). In the case of Greece, the ILO supervisory bodies expressed many reservations about the impact on a number of ILO Conventions, including Conventions 87 and 98, of austerity measures adopted by this country at the request of "Troika" of creditors (the European Commission, the European Central Bank and the IMF). In Romania, the ILO and the IMF were unable to agree on a common platform of recommendations on labour protection legislation, minimum wages, and the role of social dialogue and collective bargaining during austerity. ${ }^{27}$

Admittedly, more efforts will be needed in the decades to come, in order to translate policy guidance on the importance of social dialogue in labour policy and law making, into tangible adjustment of action on the ground. Such action may build on the good practice of broadening the space for social dialogue during the design of emergency responses to the pandemic in early 2020, provided that social partners, labour administrations and social dialogue bodies continue to have a say during the design of post-COVID-19 recovery policies. 
However, the gigantic increase in national budget deficits and sovereign debts in both developed and developing economies, ${ }^{28}$ and the risk of equally sizeable austerity programmes, are likely to further test the resilience of social dialogue in the years to come, particularly as central banks, ministries of finance and IFIs regard fiscal consolidation strategies as non-negotiable.

\subsection{TRENDS IN LABOUR LAW REFORMS AND THE CONSEQUENCES FOR SOCIAL DIALOGUE}

Sound labour laws and measures for ensuring compliance with labour law (including labour inspection) are necessary complements to social dialogue: they shape frameworks for social dialogue; help to guarantee workers' rights, including freedom of association and collective bargaining rights; have a dissuasive effect that can trigger workplace cooperation. Effective labour legislation and inspection can also play a role in the progressive inclusion of firms in the informal economy and coverage of vulnerable workers by labour law protection. This in turn creates opportunities for broadening the membership base of employers' and workers' organizations and rendering social dialogue more inclusive. Furthermore, labour law enforcement institutions can play an important role by making sure that measures adopted during transitions and crisis periods do not weaken social dialogue and workers' rights. Yet, at the dawn of the ILO's centenary challenges in these areas persisted, including in countries with otherwise long traditions of labour regulation and administrations, and highly developed national, sectoral and enterprise level social dialogue frameworks.

In the last decades all the world's regions and subregions saw reforms to labour law, with the largest number of reforming countries in Central Asia and Europe. The reconsideration of aspects of national laws with the aim of reshaping industrial relations settings - including through consulting with the social partners - has demonstrated a divergent trend: on the one hand, reforms in developing countries have generally improved frameworks, as in many parts of Asia and Latin America, where social dialogue and collective bargaining have been seen as part of economic development strategies; on the other hand, in some industrialized countries, reforms have gone the other way, restricting both the scope of social dialogue and collective bargaining at the national and sectoral levels while increasing it at the workplace level (ILO, 2018b: para 44).

The latter pattern was observed especially in countries which decided to adopt structural adjustment and fiscal consolidation policies as a result of the 2008 financial and economic crisis (ILO, 2018b: para 44). These countries modified prevailing models of collective bargaining in an effort to facilitate wage adjustments that take account of regional and enterprise differences in productivity. Reforms also emphasized bargaining at enterprise rather than 
sectoral or national levels; discontinued or "froze" temporarily the extension of collective bargaining agreements; and reviewed the "favourability principle" by giving pre-eminence to enterprise level agreements (even when social dialogue actors and mechanisms were weak or absent from that level, and where their provisions derogated from those of sectoral agreements or national law). Overall, these divergent trends - between developing and industrialized countries - are progressively resulting in a de facto convergence towards social dialogue systems that may be viewed as less ambitious than earlier benchmarks established in high-income countries in the 20th century, notably in Europe. Such a "race to the middle" admittedly challenges further the prevailing models of social dialogue in many countries.

The above trends are taking place at a time when labour administrations in many countries are characterized by a lack of funding, low efficiency and serious gaps in governance (Heyes and Rychly, 2013). Ministries of labour in many industrialized countries have substantial funding, but in developing countries these ministries often receive less than 1 per cent of the state budget - too little for maintaining even basic administrative functions. The use of information and communications technology, now at reach in many countries, can constitute an important opportunity for improving labour administrations and workplace compliance (Hastings and Heyes, 2016).

\subsection{CROSS-BORDER SOCIAL DIALOGUE}

Interestingly, while social dialogue is faced with major challenges at national level, social dialogue is expanding across borders via a multitude of public inter-state initiatives aimed at promoting fundamental labour rights and other international labour standards. ${ }^{29}$ Cross-border social dialogue is developing against a backdrop of new forms of international production; increasing trade integration and foreign direct investment; a delegation of some aspects of states' economic and political sovereignty to regional integration bodies and to multilateral organizations; and the multiplication and reinforcement of multinational enterprise (MNE) global value chains. The global public health and economic crisis unleased by COVID-19 has been a further illustration that contemporary challenges do not recognize national borders and that cross-border cooperation and dialogue and agreements between governments, employers and workers are part and parcel of sound socio-economic governance.

Regional cross-border social dialogue has been firmly established particularly in the European Union (EU) where social dialogue at the cross-industry, sectoral and company levels has been institutionalized to accompany the development of the EU internal market building. Often, social dialogue at this level has reflected a widespread practice in EU member states, but also their acknowledgement that economic integration and social justice must 
go hand-in-hand. Beyond Europe, initiatives to establish cross-border social dialogue in regional groupings such as MERCOSUR, ECOWAS, SADC, UEMOA, EAC, ASEAN, OAS and CARICOM, and the organized presence of the social partners at this level, are also progressively emerging. However, such efforts are still embryonic when compared with the EU experience, while the rise of protectionist tendencies may slow down such efforts.

Numerous bilateral and multilateral trade agreements envisage consultations with national employers' and workers' organizations on the implementation of their labour provisions. They also allow any concerned entity, including workers' and employers' organizations, to submit concerns about the failure of the parties to the agreements to honour their labour commitments. However, the operationalization of social dialogue provisions has much room for improvement. A lack of capacity of institutions and social partners in certain countries, limited transparency in trade negotiations and the allocation of insufficient resources to facilitate cross-border dialogue are among the observed constraints (ILO, 2017d)..$^{30}$

At company level, International Framework Agreements (IFAs) provide a framework for social dialogue and constructive labour relations within large MNEs. IFAs are signed agreements between MNEs and Global Union Federations (GUFs) which focus on the promotion of freedom of association and the right to organize within MNE subsidiaries (more rarely their suppliers). Increasingly, they include clauses on promoting sound occupational safety and health and human resource management policies. IFAs establish social dialogue mechanisms for their sound follow-up and joint labourmanagement mechanisms for resolving labour-related disputes down the value chain of MNEs. While only a small minority of MNEs have signed an IFA, and most of them are headquartered in European countries, the agreements have implications for enterprises and workers in other regions and countries. There is evidence that IFAs can help to improve relationships between management and workers in the enterprises concerned, and to prevent and manage labour disputes, without having recourse to national labour administration and labour justice systems (Papadakis, 2011).

A growing awareness by companies that cross-border labour-management cooperation can be closely associated with global business expansion plans and human resources management, and of the benefits that companies enjoy when joining IFAs, is likely to boost this type of cross-border social dialogue in the decades to come. ${ }^{31}$ Yet, as IFAs are becoming more ambitious in terms of their references to suppliers, contractors and subcontractors (ILO, 2018c), the task of monitoring the hundreds or sometimes thousands of suppliers and subcontractors, and of making social dialogue bodies within MNEs more effective, becomes immense. 
To cope with the pandemic's impacts, multiple cross-border social dialogue instances led to important global agreements. For instance, an IOE-ITUC-IndustriALL joint statement on "COVID-19: Action in the Global Garment Industry" - a global industry heavily impacted by the crisis - called for measures to support garment manufacturers and workers. The statement commits the parties to take action to protect garment workers' income, health and employment and support employers to survive during the COVID-19 crisis, and to work together to establish sustainable systems of social protection for a more just and resilient garment industry. It also requires all relevant stakeholders to work together urgently to develop and support, including financially, concrete and specific measures. ${ }^{32}$

It should be noted that cross-border social dialogue is voluntary. With one exception (European Union treaty law, see below), it has so far developed outside a legal framework regulating its design, operation or implementation. Its outcomes are therefore not legally enforceable in the same way as most outcomes of social dialogue at country level (Moreau, 2017). Furthermore, as ILO standards - in spite of their global coverage - are addressed only to member states and focus on the national level, they are rather silent with regard to the cross-border level. For instance, Convention on Tripartite Cooperation (International Labour Standards), 1977 (No. 144) is limited to national level tripartite consultations. Similarly, the Consultation (Industrial and National Levels) Recommendation, 1960 (No. 113) has served for over 60 years as a key instrument for guiding states on measures to promote effective consultation and cooperation between government and the social partners, as well as between employers' and workers' organizations, at national and industry levels - not the cross-border level. Hence, specific guidance to labour administrations and the social partners in their endeavour to "provide an enabling environment for and promote, where appropriate, cross-border social dialogue to foster decent work, including for vulnerable groups of workers in global supply chains" is lacking. ${ }^{33}$ In that respect, the ILO Tripartite Declaration of Principles concerning Multinational Enterprises and Social Policy (MNE Declaration) remains the most authoritative instrument for encouraging the positive contribution of MNEs to economic and social progress and the realization of decent work for all, including through cross-border dialogue.

Outside the ILO, efforts to establish legal frameworks for cross-border social dialogue have existed for several decades. For instance, the 2012 Treaty on the Functioning of the European Union (TFEU) provided a legal basis for EU social dialogue and an institutional role for the social partners at this level. Furthermore, efforts at the EU level to elaborate an "optional legal framework" for transnational collective bargaining and to regulate the negotiation of IFAs and similar transnational company agreements proved unsuccessful (European Parliament, 2013). Finally, in the maritime transport sector, a fully fledged 
global collective agreement has been signed voluntarily, and is regularly updated, between a global employers' organization representing the interests of ship-owners (IMEC), and the corresponding Global Union Federation (the ITF) (Papadakis et al., 2008). Beyond this unique private endeavour, the evolution of cross-border social dialogue may largely depend on how regional and global public organizations are defining legal frameworks for cross-border social dialogue, and providing it with purpose and legitimacy. Strengthening the institutional role of global social partner organizations in such organizations will be a key step forward in this context (Hornung-Draus, 2020).

\section{7 “CIVIL DIALOGUE” VERSUS SOCIAL DIALOGUE}

Broadly speaking, "civil dialogue" refers to ad hoc, unstructured and flexible consultations on societal issues, among public authorities and a broad range of non-state actors, notably civil society organizations (CSOs) or non-governmental organizations (NGOs). It is an effort to facilitate the inclusion of multiple interest groups in policy making, and indeed render governance more inclusive. Some processes - often referred to as "Tripartite-plus social dialogue" or "Bipartite-plus social dialogue" - may also embrace actors other than the traditional social partners (Baccaro, 2001). In such cases, the frontiers between "social dialogue" and "civil dialogue" can become blurred. For instance, Economic and Social Councils and Similar Institutions frequently encompass representation going beyond labour and management, stricto senso, in order to include youth associations, women organizations, people with disabilities, community-based organization, cooperatives, and groups advocating important causes (e.g. environmental protection and so on). The involvement of CSOs in policy processes can be effective through awareness raising and information campaigns driven by human rights concerns (Baccaro and Papadakis, 2008) or, as in the case of cooperatives, may give voice to workers who, for various reasons, chose different forms of organization and representation (Eşim et al., 2020). Importantly, numerous examples of partnerships with NGOs point to a number of potential advantages to effective labour administration (Hastings and Heyes, 2016: 31-4).

Yet, expanding CSO involvement in social dialogue and labour administration does not come without risks for the social dialogue paradigm, for many interrelated reasons. First, while other bodies' acknowledgement of social dialogue as an appropriate and effective governance model creates opportunities for the ILO to promote its objectives and values, terms such as "stakeholders' consultations" and "participatory governance" may hide unrepresentative mechanisms that can undermine the purpose of social dialogue and the interests of the membership base of traditional social partners. Employers' and 
workers' organizations, and the ILO itself, may therefore express legitimate reservations with regard to dialogue processes open to civil society, notably because genuine and effective social dialogue depends on the representativeness of the organizations engaging with government and with each other, which should be based on genuine constituencies of members.

Second, the increasing use of the term "social dialogue" by other entities (including CSOs, MNEs and multilateral organizations such as the EU) may generate multiple interpretations and some confusion regarding the functioning and expected outcomes of social dialogue. "Tripartism-plus", "bipartism-plus", "civil dialogue" and other participatory processes do not follow the same rules of interaction between actors as in social dialogue stricto sensu (Baccaro and Papadakis, 2008). They rely on the practice of "deliberation", a concept whereby actors are invited to "deliberate" rather than "negotiate" or "consult" (as in most social dialogue processes). Actors are invited to reach a consensus on a specific issue based on the "exchange of good arguments" whereby the best ones are expected to prevail (contrary to bargaining where the "stronger" arguments prevail). And usually, contrary to social dialogue, they cannot lead to agreements, for instance in the sense of the ILO's Collective Agreements Recommendation, 1951 (No. 91). ${ }^{34}$

Third, research has shown that within formal processes, CSOs risk being co-opted by more powerful actors as they do not enjoy the traditional safeguards of representativeness, clear mandates and constituencies (Papadakis, 2012). Usually, single purpose organizations lack the capacity to arbitrate between conflicting interests, or may be more easily intimidated, silenced or subsumed, with the risk that "civil society" provides apparent legitimacy for the agenda of an "elite" or pre-decided policy agendas (Baccaro and Papadakis, 2009).

While most CSOs do not satisfy representativeness criteria that the traditional social partners enjoy, labour administrations and employers' and workers' organizations do recognize that CSOs can be their valuable allies, especially where trade union density and employer organization presence is low, in providing access to groups targeted by the social partners for organizing purposes (such as domestic and migrant workers or the unemployed); in opening policy space in areas going beyond the traditional scope of labourmanagement and socio-economic policy (e.g. environmental protection) ${ }^{35}$ and in achieving efficiency gains by delegating or entrusting to CSOs certain activities usually restricted to labour administrations (e.g. labour inspection), in accordance with national laws or regulations, or national practice as per Convention 150 (art. 2).

More broadly, the debate on the role of new important actors engaging in social dialogue - including CSOs and MNEs - may no doubt amplify in the years to come, due to several factors: (a) a certain dominance in international 
instruments of a "multi-stakeholder" governance model, over social dialogue, when it comes to promoting human rights due diligence for enterprises; $;^{36}$ (b) the proliferation of enterprise-driven corporate social responsibility (CSR) programmes and private compliance initiatives (PCIs) that (contrary to IFAs - Section 3.5) imply broad consultation with "all those potentially affected" by the operations of enterprises, which is only exceptionally translated into an active role for workers and trade unions in CSR and PCIs; and (c) a certain tendency in the international community to promote "good governance" initiatives that do not sufficiently distinguish between "multi-stakeholder engagement" and "civil dialogue", on the one hand, and social dialogue, on the other hand..$^{37}$

All in all, in order to avoid a watering down of the social dialogue paradigm, the ILO and its constituents have no alternative other than to consistently raise awareness in national and international settings that despite the proliferation of CSOs in recent decades and a regression in trade union membership, workers' organizations remains the largest social movement in most countries and globally, representing more than 200 million affiliated workers; that business and employer organizations continue to see workers' organizations as their preferred civil society counterpart; and that employers' and workers' organizations are distinct from other civil society groups in that they represent clearly identifiable actors of the real economy and draw their legitimacy from the members they represent.

\subsection{CONCLUSION: THE NEED FOR TRUST AND CONFIDENCE IN SOCIAL DIALOGUE AND DEMOCRACY}

Efforts to address governance gaps by reference to social dialogue might prove important if labour administrations are to successfully perform their roles of following the development of the social situation, supervising the implementation of legislation, and ensuring the sound operation of social dialogue and industrial relations machineries and institutions. ${ }^{38}$ The 2019 report of the Global Commission on the Future of Work, which underpinned the ILO Centenary Conference and its main outcome, ${ }^{39}$ made a handful of recommendations, many of which relate, more or less directly, to the challenges also highlighted in the present chapter. ${ }^{40}$

The report recalled the Preamble to the 1919 ILO Constitution which emphasizes that lasting peace and stability depend on social justice - a principle that is as valid today as it was back in 1919. It described social dialogue as "a public good that lies at the heart of democracy". It called "for public policies to promote collective representation and social dialogue", with a view to achieving a "new social contract" that will help to navigate future of work 
transitions (ILO, 2019a: 41). And it recommended inter alia that "all countries establish national strategies on the future of work, relying for their development on existing institutions for social dialogue or, as necessary, establishing new ones", placing emphasis on the need for enhancing inclusiveness and representativeness (ILO, 2019a: 55).

The Commissioners' report largely shaped the International Labour Conference debates that led to the ILO's Centenary Declaration for the Future of Work (ILO, 2019b). In line with the spirit of the report, the Declaration adopted a "human-centred approach" focusing on three areas of action: increasing investment in people's capabilities; increasing investment in the institutions of work; and increasing investment in decent and sustainable work. It recognized, inter alia, that "social dialogue contributes to the overall cohesion of societies and is crucial for a well-functioning and productive economy" (ILO, 2019b: para 7, preamble). And that "social dialogue, including collective bargaining and tripartite cooperation ... contributes to successful policy and decision-making in its member States" (ILO, 2019b: II-B).

In our view, the success of member States' effort to implement the ILO Centenary Declaration for the Future of Work will ultimately depend on how they will address a key concern raised by the Commissioners but not reflected in the Declaration: "eroding trust in institutions" (ILO, 2019a: 21).

Admittedly, the mere presence of national legislation and labour administrations, bipartite and tripartite national or sectoral dialogue mechanisms, and private and public cross-border social dialogue endeavours, cannot on its own affirm the value of social dialogue as a means for achieving social justice, and for addressing world of work challenges in the 21 st century. What is also needed is trust in the value of social dialogue as a democratic institution; trust among policy actors; and political will denoting a commitment by governments, the social partners and the broader civil society to good faith cooperation.

In many countries there is no culture of dialogue or trust among the tripartite partners, particularly where labour markets are dominated by informal jobs and where inequalities thrive. In some countries, governments make only declarative statements on social dialogue, and social partners' involvement in policy making is improvised or the government invites their contribution too late to have much impact. The capacities of national labour administrations, such as ministries, tripartite councils, labour inspectorates and vocational training institutions, vary considerably across ILO member States, with many experiencing remarkable institutional and budgetary deficits.

The ILO's action to support constituents will continue to focus on upgrading frameworks for all forms of social dialogue, by helping them to ratify and effectively implement core ILO Conventions and Recommendations, ${ }^{41}$ and other important international labour standards from a governance perspective ${ }^{42}$ 
- all denoting the key role that labour administrations and social partners have to play in creating an enabling environment for promoting social justice and social peace.

Yet, the ILO cannot legislate on or impose trust and confidence in democratic institutions -including the institution of social dialogue, which is part and parcel of democracy. The Economist Intelligence Unit (EIU) Democracy Index 2018 highlights important concerns in relation to declining levels of public trust in institutions, in the face of uncertainty about or vulnerability to the actions of institutions. It notes that voters around the world are clearly disillusioned with formal political institutions and are deeply divided; and that amid deteriorating societal consensus and cohesion to underpin a stable, functioning democracy and a deepening of political polarization, political effectiveness is complicated and institutions weakened. Importantly, it highlights that an observed rise in political engagement, combined with deteriorating civil liberties, augur instability and social unrest in the decades to come (EIU, 2018).

It is worrisome that while in the past such trends may have been observed mostly in young and transition democracies, they are now affecting countries with otherwise deep-rooted democratic traditions, such as in Europe and North America. In this context, challenges for labour administrations and the social partners in harnessing social dialogue's full potential in addressing socio-economic matters are likely to persist, and perhaps increase. From this viewpoint, the journey for implementing the highly relevant ILO Centenary Declaration might be reminiscent of Odysseus' journey to reach Ithaca.

\section{NOTES}

1. The pros and cons of the interplay between public policy making and broad societal participation in it - also described as "deliberative public administration" - has been analysed inter alia in Baccaro and Papadakis (2009).

2. C150 - Labour Administration Convention, 1978 (No. 150).

3. Article 1 (d) of the 1944 Philadelphia Declaration states: "The war against want requires to be carried on with unrelenting vigour within each nation, and by continuous and concerted international effort in which the representatives of workers and employers, enjoying equal status with those of governments, join with them in free discussion and democratic decision with a view to the promotion of the common welfare."

4. The ILO is the only UN agency with a tripartite governance structure that includes government, employer and worker representatives.

5. By early September 2020, the pandemic had affected more than 27 million individuals worldwide, killing close to 900,000 . According to ILO estimates, by July 2020 large-scale workplace closures around the world in response to COVID-19 had led to a reduction in hours worked of 14 per cent worldwide in the second quarter of 2020 relative to the last quarter of 2019. That translated into the loss of 400 million full-time jobs (calculated on the basis of a 48-hour working week). In 
the sectors most affected by the COVID-19 crisis - such as wholesale and retail trade and accommodation and food services - no less than 436 million enterprises (employers and own-account workers) were at high risk of serious disruption. According to International Monetary Fund (IMF) estimates, the world GDP growth rate was projected to fall by 3 per cent (as opposed to the 2008 crisis, in which it dropped by 0.3 per cent), while the cumulative loss to global GDP over 2020 and 2021 from the pandemic crisis could be around 9 trillion dollars, greater than the economies of Japan and Germany combined. See https://blogs.imf .org/2020/04/14/the-great-lockdown-worst-economic-downturn-since-the-great -depression/ (accessed 20 April 2020).

6. Notably, the 1st Recurrent discussion on "Social Dialogue" under the 2008 Declaration on Social Justice for a Fair Globalization, ILC, 102nd Session, June 2013; the 2nd Recurrent discussion on "Social Dialogue and Tripartism", ILC, 108th Session, June 2018; and the Tripartite Meeting of Experts on "Cross-border social dialogue", Geneva, 12-14 February 2019. The author of the present chapter was the lead author of the background documents that served as a basis for discussion at the above three instances.

7. For recent accounts of these interrelated questions see ILO (2015b), Berg (2015), ILO (2016a), ILO (2019a).

8. As of September 2020, the Tripartite Consultation (International Labour Standards) Convention, 1976 (No. 144) had been ratified by 153 countries, that is, over 80 per cent of ILO member states. The number of social dialogue institutions and mechanisms has historically been lifted by the promotion and ratification of this Convention.

9. The Migrant Workers (Supplementary Provisions) Convention, 1975 (No. 143), the Migration for Employment Recommendation (Revised), 1949 (No. 86), and the Migrant Workers Recommendation, 1975 (No. 151) require member states to involve the social partners in providing services for migrant workers and consultations on international labour migration.

10. Higher costs of commodities deemed particularly polluting may imply increased inequality as lower income groups of people may be more affected, as well as social unrest or larger conflicts (e.g. as seen in the "gilets jaunnes" protests in France).

11. Participatory governance is indeed a central element of socially sustainable development because it constitutes the primary means through which this concept takes concrete form, in other words, it is the means through which it may be decided which "mix" of often antithetical objectives and policies may be seen as acceptable by all stakeholders affected by a specific development issue, policy, project and so on. The specific mix of policies is therefore to be discussed by a wide range of stakeholders who attempt to promote the specific interests of their constituencies. Participatory governance is the "vector" through which socially sustainable development may be put to effect. See Papadakis (2006).

12. For instance, in Mexico, Mauritius and Uruguay the reviews from such assessments fed into the formulation of national policies that support the creation of decent work, green jobs and social dialogue, in the transition to the green economy. See http://www.ilo.org/global/topics/green-jobs/publications/assessments/lang--en/ index.htm (accessed 10 April 2020).

13. See World Bank's cross-time estimations at https://ourworldindata.org/wp -content/uploads/2013/05/World-Poverty-Since-1820.png (accessed 20 May 2020). 
14. For a recent account, see Baccaro and Galindo (2018).

15. C. Lagarde, President of European Central Bank, estimates that due to the COVID-19 crisis supply chains would shrink by around 35 per cent and the use of robots would increase by between 70 per cent and 75 per cent. See W. Horobin and A. Rajbhandari (2020), "ECB's Lagarde Expects Disinflation as Crisis Transforms Economy", Bloomberg Economics (4 July 2020).

16. S. Dixson-Declève, H.J. Schellnhuber, and K. Raworth (2020), "Could COVID-19 give rise to a greener global future?" World Economic Forum (25 March 2020).

17. In addition to limitations to freedom of movement during the lockdown, over 50 countries have postponed elections, at times with little certainty as to when and how they will be held (International Institute for Democracy and Electoral Assistance, 2020). Further, according to a recent a survey of 142 states, while emergency measures seem to present little or no threat to democracy in 47 states, 82 states are at high (48) or medium (34) risk, with the pandemic response either accelerating or emphasizing established trends of democratic decay (V-Dem Institute, s.d.).

18. Resolution concerning the second recurrent discussion on social dialogue and tripartism, adopted by the General Conference of the International Labour Organization, meeting at its 107th Session, 2018 on 7 June 2018.

19. Vulnerable categories of workers include: migrant workers, workers with disabilities, ethnic minorities, tribal and indigenous peoples, rural and agricultural workers, domestic workers, workers in export processing zones, workers in the informal economy and workers in non-standard forms of employment.

20. The proportion varies significantly between different regions of the world, with Africa in first place ( 85.8 per cent), followed by the Arab States (68.6 per cent) and Asia and the Pacific (68.2 per cent). See ILO (2018a). These figures could be readjusted upwards due as a result of the COVID-19 pandemic.

21. For a recent account, see ILO (2017c).

22. Notably, the 2012 Recommendation 202 on Social Protection Floors; the 2013 Domestic Workers Convention No. 189; the 2015 Recommendation No. 204 concerning the Transition from the Informal to the Formal Economy; or the 2017 Recommendation No. 205 on Employment and Decent Work for Peace and Resilience Recommendation.

23. In the ILO (2008: 8) its Declaration on Social Justice for a Fair Globalization inter alia states that the organization "must ensure coherence and collaboration in its approach to advancing its development of a global and integrated approach, in line with the Decent Work Agenda and the four strategic objectives of the ILO, drawing upon the synergies among them".

24. Inequality has become a standing debate at the Davos World Economic Forum. OXFAM's World Inequality Report 2018, launched in January 2019 in Davos, showed that the persistence of wealth concentration to a minority of population: between 1980 and 2016 the poorest 50 per cent of humanity only captured 12 cents in every dollar of global income growth. By contrast, the top 1 per cent captured 27 cents of every dollar. The trend seems unstoppable: compared to 2017, OXFAM's reports shows that the poorest half of the world became 11 per cent poorer, while billionaires' fortunes rose 12 per cent - or $\$ 2.5$ billion every day. See World Economic Forum (2019).

25. Recourse to social dialogue was observed as part of the response to the COVID-19 crisis in the majority of ILO member states, that is, in 134 countries out of 188 states and territories. See ILO (2020c). 
26. For a comprehensive, reference book which evaluates the economic effects of unions and collective bargaining, see Aidt and Tzannatos (2002).

27. In Romania, a new law on social dialogue abolished the collective agreement at national level and dismantled the automatic extension of collective agreements at sectoral level, effectively limiting the scope of collective bargaining. The law also tightened the representativeness requirements, making trade union action harder. ILO: Social dialogue, 2013, para 110.

28. The IMF predicts that in 2020, relative to the January 2020 World Economic Outlook, fiscal deficits are expected to be more than five times higher in advanced economies (AEs) and to more than double in emerging market economies (EMEs), leading to an unprecedented jump in public debt of, respectively, 26 and 7 percentage points of GDP. See IMF (2020: 4); UN/DESA (2020).

29. For an overview of the history and prospects of cross-border social dialogue, see Papadakis (2021).

30. ILO (2017d).

31. Using a game theory model recent research shows that MNEs profit substantially from such endeavours. See Luterbacher et al. (2017).

32. https://www.ilo.org/global/topics/coronavirus/sectoral/WCMS_742343/lang--en/ index.htm (accessed 20 May 2020).

33. International Labour Conference: Resolution concerning the second recurrent discussion on social dialogue and tripartism, adopted on 7 June 2018, para 3 (o).

34. Paragraph 2(1) of the Collective Agreements Recommendation, 1951 (No. 91) defines collective agreements as: "all agreements in writing regarding working conditions and terms of employment concluded between an employer ... or one or more employers' organisations, on the one hand, and one or more representative workers' organizations ... on the other".

35. The 2002 ILO resolution on social dialogue and tripartism addresses this possibility of alliances with CSOs, while calling attention to the need for representativeness of such organizations. See ILO (2002).

36. For instance, the UN Guiding Principles on Business and Human Rights: Implementing the United Nations "Protect, Respect and Remedy" Framework (UNGPs).

37. For instance, the 2030 Agenda and the SDGs or the ongoing UN reform emphasize the role of "civil society", "NGOs" and the "business community", rather than that of trade unions and employers' associations.

38. Paraphrasing Valtikos's (1979) definition of labour administration (cited in Heyes and Rychly, 2013: 2).

39. That is, the ILO Centenary Declaration for the Future of Work, adopted by the International Labour Conference at its 108th session, Geneva, 21 June 2019 (ILO, 2019b).

40. Recommendations relate, inter alia, to the need for more investment in lifelong learning, a guaranteed social protection and a universal labour guarantee that enshrines an adequate living wage, maximum limits on working hours, and protection of safety and health at work (ILO, 2019a, note 6).

41. Notably, the Freedom of Association and Protection of the Right to Organise Convention, 1948 (No. 87), and the Right to Organise and Collective Bargaining Convention, 1949 (No. 98).

42. Notably, the Labour Inspection Convention, 1947 (No. 81), Labour Inspection (Agriculture) Convention, 1969 (No. 129), the Employment Policy Convention, 1964 (No. 122), the Tripartite Consultation (International Labour Standards) 
Convention, 1976 (No. 144), and the Labour Administration Convention, 1978 (No. 150).

\section{REFERENCES}

Aidt, T., and Tzannatos, Z. (2002), Unions and collective bargaining - economic effects in a global environment, Washington DC: World Bank.

Baccaro, L. (2001), "Civil society, NGOs, and decent work policies: Sorting out the issues", IILS Discussion Paper 127, Geneva: International Institute for Labour Studies.

Baccaro, L., and Galindo, J. (2018), “Are social pacts still viable in today's world of work?" Governance and Tripartism Department, Geneva: ILO.

Baccaro, L., and Papadakis K. (2008), "The promise and perils of participatory policy making", IILS Research Series 117. Geneva: International Institute for Labour Studies.

Baccaro, L., and Papadakis K. (2009), "The downside of participatory-deliberative public administration", Socio-Economic Review, 7(2), 245-76.

Berg, J., (2015), "Labour market institutions: The building blocks of just societies", in Berg, J. (ed.), Labour markets, institutions and inequality: Building just societies in the 21st century. 1-38. Geneva: ILO and Edward Elgar.

EIU (Economist Intelligence Unit) (2018), "Democracy Index 2018: Me too? Political participation, protest and democracy". Available at https://www.eiu.com/public/ topical_report.aspx?campaignid=Democracy2018 (accessed 20 January 2020).

Eşim, S., Katajamäaki W., and Tchami, G. (2020), "Cooperatives and fundamental principles and rights at work: Natural disposition or commitment to action?", in B. Roelants, H. Eum, S. Esim, S. Novkovic, and W. Katajamäki (eds), Cooperatives and the world of work, Abingdon, UK and New York: Routledge, Chapter 3.

European Parliament (2013), Report on cross-border collective bargaining and transnational social dialogue (2012/2292 (INI)), Strasbourg: European Parliament.

Hastings T., and Heyes, J. (2016), Comparative developments in labour administration, Geneva: ILO.

Hayter, S. (2015), "Introduction: What future for industrial relations?" International Labour Review, 154, 1-4.

Hayter, S., and Weinberg, B. (2011), "Mind the gap: Collective bargaining and wage inequality", in Hayter, S. (ed.), The role of collective bargaining in the global economy, Geneva: ILO, pp. 136-86.

Heyes, J., and Rychly, L. (eds) (2013), Labour administration in uncertain times: Policy, practice and institutions, Cheltenham, UK and Northampton, MA, USA: Edward Elgar and ILO.

Hornung-Draus, R. (2020), "Cross-border social dialogue from the perspective of employers", European Labour Law Journal, 1-12.

ILO (2002), Resolution concerning tripartism and social dialogue, International Labour Conference, 90th Session, Geneva: ILO.

ILO (2008), Declaration on Social Justice for a Fair Globalization, Geneva: ILO.

ILO (2013), Social dialogue: Recurrent discussion under the ILO Declaration on Social Justice for a Fair Globalization, Report VI, paras 15-16, International Labour Conference, 102nd Session, Geneva: ILO.

ILO (2015a), Global Wage Report 2014/15: Wages and income inequality, Geneva: ILO. 
ILO (2015b), World Employment and Social Outlook: The changing nature of jobs, Geneva: ILO.

ILO (2016a), Non-standard employment around the world: Understanding challenges, shaping prospects, Geneva: ILO, pp. 208-15.

ILO (2016b), Promoting fair migration: General Survey concerning the migrant workers instruments, Report III (Part 1B), International Labour Conference, 105th Session, Geneva.

ILO (2017a), Addressing governance challenges in a changing labour migration landscape, Report IV, International Labour Conference, 106th Session, Geneva, 2017, para 59.

ILO (2017b), Synthesis Report of the National Dialogues on the Future of Work, Geneva: ILO, pp. 61-4.

ILO (2017c), "Transition to formality: The critical role of social dialogue", DIALOGUE. In Brief, Issue No.1, Geneva, March.

ILO (2017d), Handbook on assessment of labour provisions in trade and investment arrangements, Studies on Growth with Equity, Geneva: ILO.

ILO (2018a), Women and men in the informal economy: A statistical picture, third edition, Geneva: ILO.

ILO (2018b), Social dialogue and tripartism, 108th Session of the International Labour Conference, para 44.

ILO (2018c), International Framework Agreements in the food retail, garment and chemicals sectors: Lessons learned from three case studies, ILO: Geneva.

ILO (2019a), Work for a brighter future. Global Commission on the Future of Work, Geneva: ILO.

ILO (2019b), ILO Centenary Declaration for the Future of Work, 118th session of the International Labour Conference, 21 June.

ILO (2020a), ILO Monitor: COVID-19 and the world of work, fifth edition, Geneva: ILO, 30 June.

ILO (2020b), "Employers and workers negotiating measures to prevent the spread of COVID-19, protect livelihoods and support recovery: A review of practice", Brief, Geneva: ILO.

ILO (2020c), "Social dialogue as a governance tool during the COVID-19 pandemic: Global and regional trends and policy issues", Research Brief, Geneva: ILO, 23 October.

IMF (International Monetary Fund) (2015), Guidance Note for Surveillance under Article IV Consultation, May.

IMF (International Monetary Fund) (2020), "Fiscal Monitor, Chapter 1: Policies to support people during the COVID-19 pandemic", 8 April.

International Institute for Democracy and Electoral Assistance (2020), "Global overview of Covid-19: Impact on elections", June. Available at https://www.idea .int/news-media/multimedia-reports/global-overview-covid-19-impact-elections \#ELECTIONS\%20HELD\%20AMID\%20COVID-19 (accessed 20 April 2020).

Johnston, H., and Land-Kazlauskas, C. (2018), "Organizing on-demand: Representation, voice, and collective bargaining in the gig economy", working paper, Conditions of Work and Employment Series No. 94, Geneva: ILO.

Luterbacher, U., Prosser, A., and Papadakis, K. (2017), "An emerging transnational industrial relations? Exploring the prospects for cross-border labour bargaining", International Labour Review, 156(3-4), 309-43.

Moreau, M.A. (2017), La spécificité des accords mondiaux d'entreprise en 2017: Originalité, nature, fonctions, Paris: ILO. 
Papadakis, K., (2006), "Socially Sustainable Development and Participatory Governance: Legal and political aspects", IILS Discussion Paper No. 166, Geneva: ILO.

Papadakis, K. (2011) (ed.), Shaping global industrial relations: The impact of international framework agreements, Basingstoke, UK and New York: Palgrave Macmillan and Geneva: ILO.

Papadakis, K. (2012), "Global Framework Agreements: Bridging social dialogue and civil dialogue?" in De Munck, J., Didry, C., Ferreras, I., and Jobert, A. (eds), Renewing democratic deliberation in Europe: The challenge of social and civil dialogue, Travail \& Société/Work \& Society 73, Brussels and Berlin: Peter Lang, pp. 133-49.

Papadakis, K. (2021), "A short history and future prospects of cross-border social dialogue and global industrial relations agreements", in Delautre, G., Echeverria Manrique, E., and Fenwick, C. (eds), Decent work in a globalized economy: Lessons from public and private initiatives, Geneva: ILO.

Papadakis, K., and Ghellab Y. (eds) (2014), The governance of policy reforms in Southern Europe and Ireland: Social dialogue actors and institutions in times of crisis, Geneva: ILO.

Papadakis, K., Casale, G., and Tsotroudi K. (2008), "International framework agreements as elements of a cross-border industrial relations framework", in Papadakis, K. (ed.), Cross-border social dialogue and agreements: An emerging global industrial relations framework?, Geneva: ILO, pp. 67-87.

TUDCN (Trade Union Development Cooperation Network) and ILO (2018), "The contribution of social dialogue to the 2030 Agenda Formalising the informal economy", Research Paper 2.

UN/DESA (United Nations Department of Economic and Social Affairs) (2020), "COVID-19 and sovereign debt", Policy Brief 72, 14 May.

V-Dem Institute (s.d.), "Pandemic backsliding", Sweden: Department of Political Science, University of Gothenburg. Available at https://www.v-dem.net/en/our -work/research-projects/pandemic-backsliding/ (accessed 15 April 2020).

World Economic Forum (2019), "The shocking truth about inequality today: OXFAM report to the World Economic Forum Annual Meeting". Available at https://www. weforum.org/agenda/2019/01/the-shocking-truth-about-inequality-today/ (accessed 20 February 2019). 